\title{
The Process of Risk Management: Sketching the Providers of Islamic Micro- Finance
}

\author{
Dr. Muhammad Awais \\ Assistant Professor (Finance), Department of Economics \& Finance, Faculty of \\ Management Sciences, Foundation University Islamabad, Pakistan \\ (m.awais@fui.edu.pk) \\ Dr. Mohamed Asmy bin Mohd Thas Thaker \\ Associate Professor, Department of Economics, International Islamic University \\ Malaysia (IIUM), Gombak Campus \\ (asmy@iium.edu.my) \\ Asif Raza \\ Head of Operations, DPL Pvt. Ltd, Islamabad \\ (asifrizvi@hotmail.com) \\ Usama Usman
}

Lecturer, Department of Business Administration, Faculty of Management Sciences, Foundation University Islamabad, Pakistan \& PhD Scholar, Xian Jiaotong University,

China (Online)

(usama.usman@fui.edu.pk)

Muhammad Mohsin

MS (Finance), Riphah International University, Rawalpindi, Pakistan

(msmohsinabidy@gmail.com)

$\&$

Dr. Omar Khalid Bhatti

Associate Professor, Istanbul Medipol University, Turkey

(omar.k.bhatti@gmail.com)

\begin{abstract}
With the assistance of using comparative analysis and interviews, we have formulated study on two discreet types of Islamic microfinance institutions: Non-government organizations \& Commercial financial institutions. This has relatively been done with the help of taking into consideration the systematic disbursement and repayment methods. Conclusively, both of the companies were susceptible to Shariah risk, operational risk and credit risk. Furthermore, company $\mathrm{B}$ has a well renowned goodwill in the market therefore, it is prone to reputational risk as well.
\end{abstract}


Keywords: Risk Management, Islamic, Micro-finance

\section{INTRODUCTION}

A system that influences institutional processes for instance, controller's appointment and organizing the production of goods and services, was much needed in the wake of financial crises (Carnell, Macey, Miller, \& Conti-Brown, 2021). The need of shifting from debt financing instruments to financing instruments was consequential because all the previous Asian crises and subprime crises were caused by debt financing. This ultimately helps the firms to move from risk sharing between all the companies to risk shifting from one company to another.

So due to the emergence of Islamic finance, it has been considered as a trivial matter by the western economies. But ever since the crises emerged the current financial systems developed by western economies have been impeachable (Blanton, Fargher, Feinman, \& Kowalewski, 2021). This merely happened because those systems are based on debt instruments. On the opposite side, Islamic finance provides its substitute in the form of qualifying debt instruments and magnifying asset instruments. So in order to bring colossal changes to current financial debt conditions, there's a need of principle compliance and regulatory authorities.

Islam is a multi-centuries old religion that originates from sixth century. It follows its principles based on Sunnah, Sharia, Quran and it takes Allah as the only ultimate, supreme and sovereign power. So with the accretion of economy, Islamic scholars followed traditional views of Islamic Laws which were considered as immutable (Elshurafa, 2012). So in order to keep ourselves in line with Islam, two modes were made. Traditionalists views that says that Islamic laws are immutable and modernists views which interpret the Islamic law in general terms to stabilize the economy without having to compromise Islamic principles. Nevertheless, this created a feud between modernists and traditionalists views which rendered a halt in unprecedented innovation process. So in order to alleviate feuds and boost innovation a proper communication platform needs to be constructed.

In this wake, a capitalist structure was made that was focused merely on Islamic countries and their economies so that they transmute from western capitalist models to Islamic capitalist models to 
sustain, control and to reach the potential power of their economies (Ayub, 2020). In this state of affairs, Islamic finance emerged that gave a profound boost to this idea. However, with the advent of Islamic finance, it was initially forced by western economies to follow its footsteps. This can be exemplified from Saudi Arabia; they followed western capital models which never let their economy reach its potential. In the similar context, after the 9/11 incident the Muslim investors contemplated to re-consider their investment opportunities to stay streets ahead from their competitors. This created a gap between western capitalism and Islamic capitalism (Ryan, 2020). Consequently, Islamic finance was a major point of consideration for Muslim economies because their conjoined efforts were massively required to develop an ideology that converges and accepts the risk of loss and risk of gain.

This eventually leads to create innovative products that are different from conventional banks without having to sacrifice Sharia principles (Hamid \& Aisjah, 2021). This has been considered that Sharia and Islamic jurisprudence has not been developing Islamic financial products and instruments to sustain the market.

Since Islamic banking has increased in an astronomical amount in recent scores therefore before extracting any conclusion and consequences a religious orientation from these firms we ought to confirm that these companies are rather Islamic (Uddin, Ashogbon, Martins, Momoh, Agbonrofo, Alika, \& Oserei, 2021). So once we fathom this fact, we can now understand that since Islamic banks are interest free therefore it is far better to have a Muslim board member. This would ultimately lead towards better financial performance of the firm.

In this regard, the performance of Islamic banks and risk taking behavior has already been studied. Which shows that foreign banks are more efficient than the domestic Malaysian banks (Nurfalah \& Rusydiana, 2021). In the same way, financial performance and ethnic diversity have been studied differently by different researchers. It gave no impact, negative impact and positive association on samples in different studies. With that being said General Social Survey suggest that Protestants are more conducive to growth than Catholics. Consequently an Islamic bank would understand the value of dressing more than a non-Islamic bank for instance Hijab. These nitty-gritties are not quantifiable but still they add up to give bigger returns. 
The diverse boards on the basis of race, ethnicity, and gender have already been studied with respect to the performance of the firm but with this regard the impact of religion has long been ignored (Ali, Yaacob, Parveen, \& Zaini, 2021). There are two reasons for this, first off, to increase one's wealth and shareholder's value is allowed in every religion. Secondly none of the firms operationalize on the basis of religious beliefs and faith and therefore it would be irrelevant to study religious orientation of board members with firm's performance.

Therefore, researchers have been thoroughgoing in arguing that conventional banks should out rightly be supplanted by Islamic banks because conventional banks show no or less recuperation in financial crises whilst Islamic banks exhibit more resilience during the interim.

It has been already said that myriad of microfinance banks are in their moribund phase because they cannot endure risk (Rozzani, Mohamed, \& Yusuf, 2017). This is engendered due to lack of concern with globalization. Generally, microfinance banks are financially strapped. Such as, in Malaysia multitude of microfinance, companies are dependent upon the capital provided by the government (Marr \& Tubaro, 2011; McGuire, Conroy, \& Thapa, 1998).

Microfinance can be categorized into two discreet types: Conventional \& Islamic. The conventional microfinance run their operations on the basis of loans. Conversely, Islamic banks are loath to run their operations on loan. It is rather considered as haram (Abdul Rahman, 2007). Islamic microfinance chief objectives are to serve Muslim clients as an alternative (Ali \& Abdul Rahman, 2013; Karim et al., 2008). Islamic microfinance deals with Islamic products like Qard Hassan, Bai Muajjal, Mudarabah, Musharakah and Salam.

To mitigate the risks associated with Islamic microfinance, the amalgamation, implementation and integration of unprecedented innovations with the help of novel technologies would be advantageous. The research question postulates that ' How risk affects affect Islamic microfinance in Malaysia, within the systematic parameters of disbursement and repayment systems'". To retort to this vary question, qualitative research through interview sessions and comparative analysis of the two different institutions have been constructed. 
Moreover, the risks Islamic banks face are far different than the risks that conventional banks faces due to the presence of SSB and Shariah. They are highly susceptible to credit and reputational risk if they do not follow the rules set for by Shariah. These distinctive features of risks creates a surface of Shariah Governance.

We are strewed about the assets being increased on an astronomical level for Islamic banks and Islamic finance. There is a growth of $17 \%$ each year. Thus it is expected to reach its zenith at US\$1.8 Trillion by 2019. Studies reveal that Islamic banks have been recuperating enough in global financial crises (GFC) but still their corporate governance was still under stake because of the merging of management with directors.

Islamic banks have their operations running under two-tier governance models which are massively different from their conventional banks in terms of product portfolio, production technology, customer base etc. (Safiullah \& Shamsuddin, 2019). We are shrewd about the ersatz results that the cross-group comparison analysis provides because it uses just one frontier for measuring efficiency.

The comparison of conventional and Islamic banks have been under discussion from last score. Myriad of studies have been conducted in order to figure out the efficiency of both the banks, Islamic and conventional.

The paper's outset is based upon introduction, followed up by the review of literature. Then with the methodology. After that meticulous lucubration has been penned down regarding the interviews conducted in findings section. Then a scrutiny and analysis of the findings within managerial conclusions are provided, this concludes the paper.

\section{REVIEW OF LITERATURE}

Microfinance deals with miniature services being provided to the indigent sector. They are usually not being entertained by commercial financial firms. Microfinance is further divided into two categories; first one is Islamic which follows principles and laws to deliver itself as an alternate to Muslims. The other one is conventional which follows the formal application of interest to the loans provided (Rozzani, Mohamed, \& Yusuf, 2017). Islamic products are provided as Qard 
Hassan, Bai Muajjal, Murabahah, Musharakah and Salam. The chief question this study answers is how risks are directly or indirectly influencing the Islamic micro-financing in Malaysia. Usually Islamic micro-financing exhibits more risk than conventional and it requires higher risk management.

Islamic finance has been proliferating ever since 1970. And it has been more widespread than conventional banks all around the world. Most of the Islamic finance and banking has been concentrated in Middle East. Despite the US\$1.6 Trillion boost in the Islamic finance, Islamic researchers are still loath to accept Islamic finance. Due to this discrepancy Journal Corporate Finance was developed in order to display all the developed and well-functioning Islamic Finance. The main objective is to lower down the cost of capital in Islamic, debt and equity markets.

On the comparison of Islamic bonds with conventional bonds, Islamic bonds yield less than conventional bonds. It is lower by the $75 \%$ (Uluyol, 2021). This difference exists because of discrepancy of taste preferences of investors in Islamic and conventional bonds. In order to substantiate it, the researchers (Al Mamun, Hassan, Azad, \& Rashid, 2021; Majumdar \& Puthiya, 2021) added a variable with Islamic bonds and it relatively showed negative coefficient. The variable measured the macro demand, turns out the same result Islamic bonds yields less than conventional bonds. Islamic investors are usually looking forward to Socially Responsible Investments but they also ask for discounts in haram or sin stocks. Thus halal investments tend to perform lower than haram stocks. A study shows that the mixed results of Shariah compliant stocks were seen through these results i.e. samples were tested in non-Muslim majority countries and it was manifested that Shariah-compliant stocks are related to norms that Muslims impose in their countries.

Myriad of governance issues and cost of capital issues can be seen in between conventional and Islamic banks (Gjergji, Vena, Sciascia, \& Cortesi, 2021). Islamic banks are asset based; they are more focused on sharing the risk between the investor and bank. Other difference is about monitoring the banks for instance, sharing the risk makes the depositors to oversee the banks but banks act in the formal interests of share and equity holders. In the same way Islamic banks perhaps 
have more transaction costs along with taxes (Hoque \& Liu, 2021). They have reduced efficiency due to management of inventory and dealing with real assets.

To stay streets ahead and sustain the competitive advantage, it is momentous for the companies to adapt cost-cutting strategies. This is profoundly challenging for financial services sector because it is more prone towards higher risks. Studies shows that sector of financial services are susceptible to higher risks of cybercrime (Clark et al., 2014). Multitude of risks have already taken over the companies due to globalization and technological advancements, thus to ameliorate this expansion of risk management and risk assessment strategies have to be accounted for (Bodur, 2012). One of astronomical risks for these institutions is credit risk. This is engendered because of indebtedness of the client to pay back the amount. Credit risk has a direct relationship with loans (Churchill \& Coster, 2001; Hussain et al., 2012; Lascelles et al., 2014; Manan et al., 2014).

Further studies articulate that only one risk is not culpable for influencing the companies. All the risks including liquidity, market conditions and transactions are interdependent and associated with each other (Khan \& Ashta, 2013). This is one of the reasons that financial services sectors especially microfinance are susceptible to fraudulent activities. Despite the fact, both conventional and Islamic microfinances face the same amount and types of risks, nevertheless, the risk for Islamic bank increases due to different types of operations it runs (Shah, Sukmana, \& Fianto, 2021).

Apart from credit risks, liquidity risks, foreign currency risk also extends threat to the institutions (Bruett, 2004; Castellani \& Cincinelli, 2015). Lastly, merely identification of these risks is not an objective. To face these challenges and to uproot them is the main objective. Mostly, microfinance providers have a fair dealing and a sound two sided relationship with their clients. However, this tends to diminish once the risk starts posing threats to the institution (Lascelles, 2012).

Operational risk is the chiefly one of the colossal source of downfall or distress caused in financial institutions. Islamic financial institutions are streets ahead in being luculent with transparency than conventional financial institutions. And it is also more consequential in Islamic financial institutions than conventional financial institutions. This assuages the informational access at the top management and it diffuses it to all the participants. It also instills a characteristic of flexibility which renders supervisors and public with greater understanding of financial institutions strategies 
(Neifar \& Jarboui, 2018). The biggest risk for Islamic Financial Institutions (IFI) is margin risk and then comes operational risk. The former risk is instigated due to abysmal human resource strategies and poor systematic legislation.

To ensure transparency risk disclosure has to be taken into consideration. This provides confidence of market and investors to maintain and sustain the performance of enterprise. The up to scratch corporate governance proffers assistance with better quality of financial information. Operational risk is the biggest and influential cause of making the banks financially strapped.

Studies found that Islamization followed by banks have the same insolvency risk as do conventional banks, however some of the studies suggest volt-faced scenario. Other studies (Daoud \& Kammoun, 2020; Saeed, Izzeldin, Hassan, \& Pappas, 2020; Smaoui, Mimouni, \& Temimi, 2020) apprise that Islamic banks are higher on the scale of insolvency risk than do conventional banks. The case is similar and different for credit risks in other studies. This usually happens due to unmatched and non-comparable samples. This paper contributes in the extant knowledge in the following ways.

Consequently, Islamic banks are more prone to liquidity risk but they are less susceptible to credit and insolvency risk than conventional banks (Safiullah \& Shamsuddin, 2018). However, they cannot be distinguished on the basis of operational risks.

Most of the studies (Abdullah \& Asutay, 2021; Budi, 2021; Jan, Lai, \& Tahir, 2021) showed that the implementation of Islamic corporate governance would only do well. It communicates the message of accountability, justice, consultation, integrity, truthfulness, sincerity, intention and brotherhood. It interacts and delivers only good measures to be taken into account with, domestically and within global arena. So, all these elements as discussed in this paragraph are pivotal constructs of Islamic corporate governance.

With that being said, Al-Janadi, Rahman, and Omar (2013) concluded Islamic corporate governance assists the values, customs, traditions, integrity, and legislation in daily business operations and dealings. This is better than the previous corporate governance structure applied in the world (Azid, Mukhlisin, Akbar, \& Tahir, 2021). 
Erstwhile studies have shown that leverage provides good quality of corporate governance. Which means that companies with an 'Islamic name or Islamic Label', will have lower leverage than the other firms (Hayat \& Hassan, 2017). In this state of affairs the quality of corporate governance in Islamic firms would outperform whereas the quality of non-Islamic firms would underperform. However this hasn't been reckoned to be the case. There is no substantial difference in quality of corporate governance while scrutinizing the S\&P 500 firms. Apart from that there is also no substantial affect by the label of Islam on the firms. Conversely, there is a contrary end to this conversation; the label of Islam adds approximately $2 \%$ points to the quality of governance.

Some researchers (Haubrich, 1994; Shah, 2014; Thomas \& Worrall, 1990) have authentically proven that debt lowers down the principal-agent problem. Reason being, debt disciplines the managers so managers do not act in their self-interest and they also do not squander the money when they have debt to pay. If for instance we consider that corporate governance, its quality and debt are interlinked with the Islamic label then it can perhaps affect it directly and indirectly.

Reporting the risk increases opaque and transparent practices. It also builds trust factors among the investors. There is little or no heed paid to risk reporting in second-world countries (Abdallah, Hassan, \& McClelland, 2015). The empirical work has established itself by reckoning risk reporting in USA, Canada, Italy, Spain, Finland, Australia and Portugal. Companies in Gulf Cooperation Council Countries are usually transparent in terms of information generation. So this evaluates Financial in terms of Islamic and non-Islamic and non-financial firms. Islamic cooperation's tend to meet higher risk reporting as governed by Islam as do conventional companies. GCC countries have same languages, reroutes, wealth etc. therefore they comply to Basel II in a same manner. This eventually leads towards similar behavior in risk reporting practices.

Usually firm size and industry type are significant predictors of corporate risk disclosure in Malaysia (Sie \& Amran, 2021). After the Global Financial Crises (GFC), UAE companies recuperated their reputation through defensive and assertive tactics. This had an impact and influence on the readers of annual reports. 
Lastly, this study not only conduces to Islamic banks but also conduces to conventional banks. To check the cost of capital and efficiency, they are dependent upon two factors Loyalty and roles of Shariah scholars in Islamic finance.

\section{CASE STUDY}

A comparative analysis has been conducted within two Islamic microfinance providing institutions. Researchers posit the advantages of comparative analysis that one can fathom prolifically the coded themes and they can be considered analogous to each other (Van Heesch et al., 2013). The usage of comparative analysis also depicts that how the implementation of different phenomena in different institutions under different environment affect the situation. This regards for two systematic disbursements and repayment systems of Islamic microfinance (Wahyuni, 2012).

The first institution is Shariah complying. They do not have their operations running on the basis of loans. They rather have their operations on the basis of two sided partnerships. They provide money on the basis of Qard Hassan, in which the client doesn't repay the loan rather they pay back the amount in the form of Ujrah. There are a lot of benefits provided from the end of institution to the clients for instance; they provide training sessions, consultation services, managing finances and enterprise development. Thus, meetings are summoned usually on Tuesdays to oversee the progress and cash payments are received. However, due to the emergence of mobile banking this has relatively been easier to do.

The second institution is somewhat same however it differs slightly. For instance, it has three main and core products that it offers to its clients. 1) Mortgage 2) Personal loan 3) Retail deposit. Nevertheless, it has been reckoned that this institution is willing to comply with a blue ocean strategy tendered by Malaysian government by underscoring savings. The microfinance products that it renders are Murabahah and Tawarruq. The good services of this institution is manifested in provision of trainings, leadership programs, establishment of businesses and making their clients astute about current and future trends so that they can mound their business accordingly. 


\section{RESEARCH DESIGN}

To provide the quintessence of triangulation to the study, an access to archival data and qualitative data was enhanced. The publications made by institution A and B for instance bulletin, brochures were thoroughgoing to gather data from eclectic sources. The qualitative studies have three characteristics. First off, it shows relatedness with theory and research in induction. Secondly, merely studying the phenomena is a confined and stagnant state because it hampers the interaction with those who are actually causing those phenomena. Therefore, communications with individuals to better assimilate the methods that yield social properties have also been incorporated (Bryman $\&$ Bell, 2011). Lastly, the interpretation of the world is made on the basis of how the participants perceive the world (Burrell \& Morgan, 1979).

The qualitative research that has been conducted is based upon semi-structured interviews to give a sense of freedom to respondents. The interviews were conducted for Risk management committee with all their consent. They were conducted in Bahasa (Malaysian language) so that the message does not get distorted. Conversely, these interviews were further lucubrated into English language for better understanding. The time span of one interview was in between 20-60 minutes. Furthermore, a narrative analysis was also conducted to oversee the comparison of disbursement and repayment methods in terms of risk-influence.

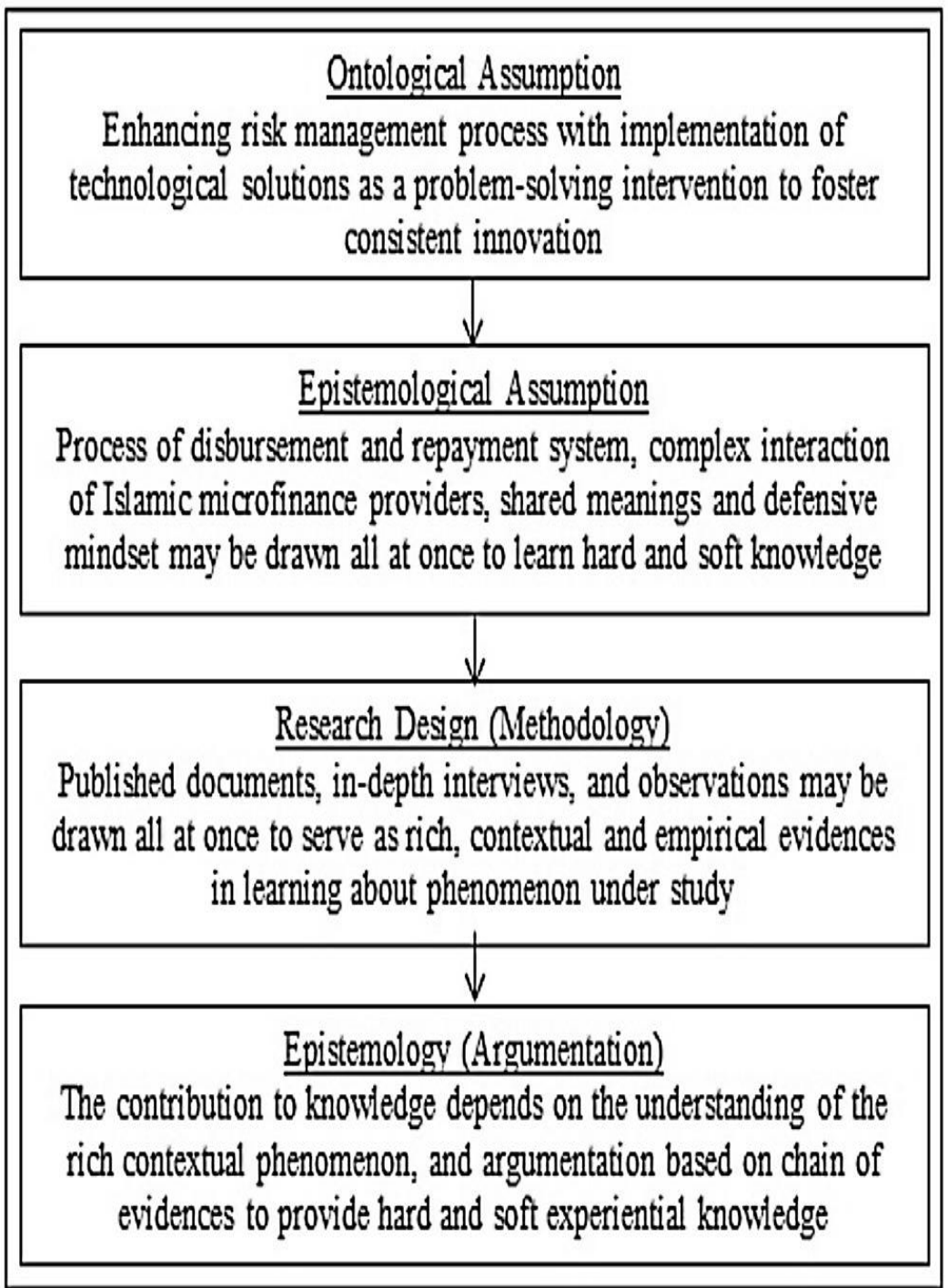


The following study is based upon social constructivist approach which means that data is thoroughly studied to oversee the phenomenon. (Creswell, 2007)

\section{FINDINGS AND DISCUSSIONS}

Institution A is posed to credit, operational and Shariah risk. Clients who are indebted or bankrupt cannot repay the amount back to the institution A which causes the misallocation and visualization of funds (Boumediene, 2011). The allocation of resources is disproportionately managed because clients tend to satisfy their own interests rather than the interests of business. They would spend the money on luxurious items instead of business ventures. Therefore inept management of the financing leads to clients who fail to meet the required payback amount (Churchill \& Coster, 2001). This usually happens because of the less pressure enforced by the microfinance companies (Sarif \& Kamri, 2009)

Operational risks has a direct relation with fraudulent activities. No matter how honest the employees are, there still exists a risk of being injected with frauds and burglary. The meetings of disbursements and repayment cash collection makes the staff of the institution more prone to robbery and burglary. As mentioned by one of the manager.

"We are used to have our staffs to carry the money collected from their centers, all the way to our headquarters here. We do that in all branches, sometimes staffs were threatened (...) Sense of insecurity is there, they need to look around to see if there are anybody following their vehicle right after every centre meeting. They carry lot of money, you see."

These fraudulent activities are first foreseen by audit committees. Through conscientiousness they search out the practices that goes against the corporate governance, rules, regulations, standard operating procedures and principles put forth by the institution. They have found out in this institution that a lot of legerdemain in terms of wrong collection of sheet, depositing the cash, incompletion of the up to the mark fund accounts is taking place. This shows that Islamic microfinance is posed with threats, fraudulent activities and subtle other discrepancies. As another manager says that: 
"There is another group that we are afraid of when we deal with large amounts of cash. Fraudsters. It may be one of our own, it could also be impostors pretending to be one of us. We have had a case like this in the past. Turns out the guy was putting up an act, he was not even a staff. Of course, when you see us handling so much money after centre meeting, who would not feel tempted? (...) With money, we can never trust anyone. Not even your family."

Apart from that manual work in Institution A is slow and also prone to human error thus to update the records, a new method should be introduced.

In the same way institution B is also susceptible to several risks including credit, operational and Shariah risk. Unlike institution A, it does not operate on the basis of Qard Hassan because it is business and profit oriented firm. They run their operation on asset based dealing for instance Tawarruq and Murabahah. The risks originates as lack of repayment by the clients, failure of the delivery of items. The concept of ghost supplier also plays its role in risk factors because clients generate invoices from the companies that do not even exist. One of the other risk is client is reluctant to buy the goods that have already been bought by the institution thus prior approval is required by the client.

"When the banks make payment, we have to check. Does the asset in question exist in the client's shop or premise? (...) All of a sudden, when staffs conduct an inspection, the machine is not there. He buys a car instead. That should not be right, don't you think?"

Inefficacious financial planning also leads to credit risk. When the clients are given more amount of micro-credit facility then clients tend to spend more than their needs and wants therefore bring the clients being financially strapped hence increasing the risk.

"For example in a restaurant, most of its capital will only be used to buy food items and related utensils, right? When we sometimes give a client a sum of loan that is more than what he needs, he splurges on that money, then he decides not to pay when he should be paying back what is due (...) So, if things happen that even we did not expect to occur, and these entrepreneurs turn out not to be doing well in their businesses, how can they pay to the bank?" (Interview 4, Institution B, Manager, own translation) "As supply, a machine helps our clients to improve their productivity (...) if really, if everything is okay, clients should experience an increase in productivity. Internal 
revenue should also be higher. The client will then have no issue to repay the bank. But if he takes the bank's money and use it to purchase other items (...) where will he get the revenue to pay back?” (Interview 3, Institution B, Manager, own translation) “Clients get cash (...) they misuse, yes. That's why we always highlight the misuse of financing that we give out (...) as they try to recover the amount that they have misused, they find that they do not have enough money to repay the bank, so they decide not to pay." (Interview 5, Institution B, Manager, own translation) Through the expansion of globalization, clients and individuals have become tech-savvy thus they have all the information at hand. Since institution B has a positive goodwill, brand image and brand equity still it is exposed towards reputational risks. Reason being, if it cannot resolve the issues faced by the clients then only one news can adversely deteriorate its already-established reputation in the market.

"If money is lost, you can still cover by insurance (...) but if reputation is lost, people would not want to bank with you. And that is the loss that the bank will have to bear." (Interview 6, Institution $B$, Manager, own translation)

With that being said, this institution faces operation risk due to the negligence of the staff in reckoning and operational activities. This negligence leads towards payment to underserved clients at the expense of loss of payment to deserving clients. They behave as a remiss in their responsibilities. They misinform the details about a client which can lead the company to pay different amount with different values to different vendors.

"Unless staffs made a mistake during payment, the client wants to pay to vendor A, but instead payment is made to vendor $B$ which has nothing to do with the business, then there are some people who should have received five thousand but suddenly receiving 30 thousand, then we have a problem there." (Interview 4, Institution B, Manager, own translation)

Furthermore Shariah risk is also a part of this company, although it tends to comply with it but still faces issues and threats. Bank Negara has rhetorically articulated the issues this bank faces while implementing Shariah Rules.

"If you don't execute properly, suddenly interest is charged to a Shariah-compliant product (...) that bank charges interest. That is wrong (...) so this voids the contract and product altogether (...) 
Clients may refuse to pay, saying that this is not Shariah-compliant as it is fallen under clause that there is an element of interest." (Interview 3, Institution B, Manager, own translation)

\section{CONCLUSION}

The findings posit that both the institutions are prone to operational, credit and Shariah risk with the same intensity with respect to disbursement and repayment systems. The gaps in institution A are taken advantage of by the clients by procrastinating the repayments. The manual and paperbased operations were also prone to human error.

For institution B, it is exposed to reputational risk. Therefore, through enlightening the risks faced by two institutions it is certainly expected that risk management processes would be better off with novel strategies to truncate the problems and discrepancies.

Concluding that, First off, Islamic institutions depict lower corporate risk than do non-Islamic institutions. Corporate Risk Disclosure is higher where there is better quality of corporate governance. Secondly and lastly, the risk disclosing practices are different for different countries.

\section{LIMITATIONS AND FUTURE RESEARCH}

The research is punctilious in provision of risks that the institutions faces through comparative analysis and interview sessions however, it does not takes into account multiple case studies to scrutinize risks of Islamic microfinances.

\section{REFERENCES}

Abdallah, A. A. N., Hassan, M. K., \& McClelland, P. L. (2015). Islamic financial institutions, corporate governance, and corporate risk disclosure in Gulf Cooperation Council countries. Journal of Multinational Financial Management, 31, 63-82.

ABDUL RAHMAN, A. R. (2007). < Islamic Economics: Theoretical and Practical Perspectives in a Global Context> Islamic Microfinance: A Missing Component in Islamic Banking. イスラ 一ム世界研究: Kyoto Bulletin of Islamic Area Studies, 1(2), 38-53.

Abdullah, H., \& Asutay, M. (2021). Constituting Islamic Corporate Governance Theory through Islamic Moral Economy. In Monetary Policy, Islamic Finance, and Islamic Corporate Governance: An International Overview. Emerald Publishing Limited. 
Al-Janadi, Y., Rahman, R. A., \& Omar, N. H. (2013). Corporate governance mechanisms and voluntary disclosure in Saudi Arabia. Research Journal of Finance and Accounting, 4(4).

Al Mamun, M. A., Hassan, M. K., Azad, M. A. K., \& Rashid, M. (2021). A HYBRID REVIEW OF ISLAMIC PRICING LITERATURE. The Singapore Economic Review, 1-33.

Ali, N., Abdul Rahman, R., 2013. Financing the poor, sustaining the provider: issue on transaction cost in microfinance program. Middle-East J. Sci. Res. 18 (4), 512-516. http://dx.doi.org/10.5829/idosi.mejsr.2013.18.4.11714.

Ali, Q., Yaacob, H., Parveen, S., \& Zaini, Z. (2021). Big data and predictive analytics to optimise social and environmental performance of Islamic banks. Environment Systems and Decisions, $1-17$.

Ayub, M. (2020). Making Islamic finance a vehicle for social inclusion: A case for revisiting the liquidity management practices by Islamic banks. In Enhancing Financial Inclusion through Islamic Finance, Volume I (pp. 109-136). Palgrave Macmillan, Cham.

Azid, T., Mukhlisin, M., Akbar, N., \& Tahir, M. (2021). Monetary Policy, Islamic Finance, and Islamic Corporate Governance: An Introductory Note. In Monetary Policy, Islamic Finance, and Islamic Corporate Governance: An International Overview. Emerald Publishing Limited.

Blanton, R. E., Fargher, L. F., Feinman, G. M., \& Kowalewski, S. A. (2021). The Fiscal Economy of Good Government: Past and Present. Current Anthropology, 62(1), 77-100.

Budi, I. S. (2021). The Mediation Role of Productivity in the Effect of Islamic Corporate Governance on Islamic Corporate Social Responsibility Disclosure. Journal of Accounting and Investment, 22(2), 254-275.

Carnell, R. S., Macey, J. R., Miller, G. P., \& Conti-Brown, P. (2021). The law of financial institutions. Lippincott Williams \& Wilkins.

Daoud, Y., \& Kammoun, A. (2020). Financial Stability and Bank Capital: The Case of Islamic Banks. International Journal of Economics and Financial Issues, 10(5), 361.

Elshurafa, D. (2012). Islamic Capitalism-An Imminent Reality or a Hopeful Possibility for Islamic Finance?. Arab Law Quarterly, 26(3), 339-360.

Gjergji, R., Vena, L., Sciascia, S., \& Cortesi, A. (2021). The effects of environmental, social and governance disclosure on the cost of capital in small and medium enterprises: The role of family business status. Business strategy and the environment, 30(1), 683-693.

Hamid, W., \& Aisjah, S. (2021). The Role of Consistence and Perceived Relevance for 
Sustainability of Sharia Banking. International Journal of Finance \& Banking Studies (21474486), 10(2), 89-95.

Haubrich, J. G. (1994). Risk aversion, performance pay, and the principal-agent problem. Journal of Political Economy, 102(2), 258-2

Hayat, R., \& Hassan, M. K. (2017). Does an Islamic label indicate good corporate governance?. Journal of Corporate Finance, 43, 159-174.

Hoque, H., \& Liu, H. (2021). Capital structure of Islamic banks: How different are they from conventional banks?. Global Finance Journal, 100634.

Jan, A. A., Lai, F. W., \& Tahir, M. (2021). Developing an Islamic Corporate Governance framework to examine sustainability performance in Islamic Banks and Financial Institutions. Journal of Cleaner Production, 128099.

Karim, N., Tarazi, M., Reille, X., 2008. Islamic Microfinance: An Emerging Market Niche (Focus Note No. 49). Retrieved from http://www.cgap.org/sites/default/files/ CGAP-Focus-NoteIslamic-Microfinance-An-Emerging-Market-Niche-Aug-2008.pd.

Majumdar, S., \& Puthiya, R. (2021). Role of signaling in issuance of sukuk versus conventional bonds-an empirical analysis of the bond market in the UAE. International Journal of Islamic and Middle Eastern Finance and Management.

Marr, A., \& Tubaro, P. (2011). Crisis in Indian microfinance and a way forward: Governance reforms and the Tamil Nadu model.

McGuire, P. B., Conroy, J. D., \& Thapa, G. B. (1998). Getting the framework right: policy and regulation for microfinance in Asia.

Neifar, S., \& Jarboui, A. (2018). Corporate governance and operational risk voluntary disclosure: Evidence from Islamic banks. Research in International Business and Finance, 46, 43-54.

Nurfalah, I., \& Rusydiana, A. S. (2021). THE REGIME SWITCHING OF CYCLE INSTABILITY OF ISLAMIC BANKING AND THE ECONOMY: EVIDENCE FROM INDONESIA, MALAYSIA, AND PAKISTAN. Journal of Islamic Monetary Economics and Finance, 7(2), 233-262.

Rozzani, N., Mohamed, I. S., \& Yusuf, S. N. S. (2017). Risk management process: Profiling of islamic microfinance providers. Research in International Business and Finance, 41, 20-27.

Ryan, M. (2020). 4. Terrorism and the "Great Game" in Georgia and the Caspian Basin. In Full Spectrum Dominance (pp. 114-135). Stanford University Press. 
Saeed, M., Izzeldin, M., Hassan, M. K., \& Pappas, V. (2020). The inter-temporal relationship between risk, capital and efficiency: The case of Islamic and conventional banks. PacificBasin Finance Journal, 62, 101328.

Safiullah, M., \& Shamsuddin, A. (2018). Risk in Islamic banking and corporate governance. Pacific-Basin Finance Journal, 47, 129-149.

Safiullah, M., \& Shamsuddin, A. (2019). Risk-adjusted efficiency and corporate governance: Evidence from Islamic and conventional banks. Journal of Corporate Finance, 55, 105140.

Shah, S. (2014). The principal-agent problem in Finance. CFA Institute Research Foundation L2014-1.

Shah, S. A. A., Sukmana, R., \& Fianto, B. A. (2021). Integration of Islamic bank specific risks and their impact on the portfolios of Islamic Banks. International Journal of Islamic and Middle Eastern Finance and Management.

Sie, B. N., \& Amran, A. (2021). Materiality Disclosure in Sustainability Reporting: Evidence from Malaysia. Asian Journal of Business and Accounting, 14(1), 225-252.

Smaoui, H., Mimouni, K., \& Temimi, A. (2020). The impact of Sukuk on the insolvency risk of conventional and Islamic banks. Applied Economics, 52(8), 806-824.

Thomas, J., \& Worrall, T. (1990). Income fluctuation and asymmetric information: An example of a repeated principal-agent problem. Journal of Economic Theory, 51(2), 367-390.

Uddin, G., Ashogbon, B., Martins, B., Momoh, O., Agbonrofo, H. E., Alika, S., \& Oserei, K. (2021). The banking sector and national economy. Available at SSRN 3773912.

Uluyol, B. (2021). A comprehensive empirical and theoretical literature survey of Islamic bonds (sukuk). Journal of Sustainable Finance \& Investment, 1-23. 